\title{
Utilization of Technology as Promotion Media of Cultural Tourism in Central Java
}

\author{
Veinta Sonrizky Mayo \\ Game Technology Department, Faculty of Computer Science \\ Catholic University Soegijapranata (SCU) \\ Pawiyatan Luhur IV/1, Bendan Dhuwur, Semarang, Indonesia, 50234 \\ veinta.sonrizky.mayo@gmail.com \\ Dr. Ridwan Sanjaya, SE, S.Kom, MS.IEC \\ SoegijapranataCatholic University(SCU) \\ Pawiyatan Luhur IV/1, Bendan Dhuwur, Semarang, Indonesia, 50234 \\ ridwan@unika.ac.id \\ Albertus Dwiyoga W.,S.Kom.,M.Kom \\ SoegijapranataCatholic University(SCU) \\ Pawiyatan LuhurIV/1, Bendan Dhuwur, Semarang, Indonesia, 50234 \\ yoga@unika.ac.id
}

\begin{abstract}
Tourism is an industry that is growing rapidly. It has a lot of models are offered and one of them is cultural tourism.Examples of cultural tourism is a temple and a museum. In addition to temples and museums, the government chooses to conduct activities such as Dieng Culture Festival. Through these activities, public can know more about the traditional ceremonies and moral values of Dieng.However, interest in the festival begins to decrease each year. That is because the lack of media campaign that resulted in people becoming unaware and less concerned about the cultural tourism. If it continues, the cultural attractions such as museums will sink and disappear eroded by age.In this study, will discuss ways of promoting cultural tourism through the use of technology so that cultural tourism can be known internationally
\end{abstract}

Keywords - tourism, culture, promotion, preservation, Central Java

\section{INTRODUCTION}

Many areas of tourism is a commodity in order to increase local income [1]. One of them is the Central Java tourism as one of the leading sectors in regional income. It is not independent of the location of Central Java at the center of the island of Java where the rate of economic growth is very rapid. Tourism potentials of Central Java are extremely diverse. Among them is the nature of Dieng, cultural tourism in Prambanan and Borobudur and various other attractions. Borobudur and Dieng are one of the mainstay attractions of Central Java. According Ganjar Pranowo as the Governor of Central Java, Borobudur and Dieng are tied to the social environment so attractive to attract tourists, especially foreign tourists [2]. Given that the benefit is doubled because in addition to sightseeing, tourists can also get to know and learn the culture of the region at the venue. One example is the introduction to the culture through Dieng Culture Festival event held once every year at Dieng temple area which is always crowded with visitors. The event in Dieng Culture Festivalisthe ceremonial hair cutting of dreadlocks children who are the descendants of the original residents of Dieng. At the event visitors can see first hand the cutting procession of the dreadlocks. But there are constraints in the availability of facilities and infrastructure so that not all tourists can enjoy the event. Beside the lack of media promotion and use of conventional 
promotion constrain the government in attracting foreign tourists to visit to Central Java. Therefore, according to the Head of Culture and Tourism of Central Java, Prasetyo Aribowo, the government needs to use various forms of social media and engage in the community to create more efficient promotion [3]. By leveraging technology and social media promotion, the range will be widened and tourists will get information at any time. Therefore if cultural tourism and technology are combined into one, it would produce a work which beside being media of campaign can also be used as a medium of education for children to introduce the culture of each region in Central Java.

A good promotional method is also required to allow tourists to be interested in visiting cultural attractions in Central Java. One method that can be used is to do with the selection of cultural travel destination thoroughly so people can get to know that the cultural tourism in Central Java is not only famous.

\section{LITERATUR REVIEW \\ 2.1. Definition of Culture}

Culture according to the Sanskrit word is derived from the word "Buddahyah", which is the plural of buddi that has meaning and a sense of gratitude [8]. Meanwhile, the father of Anthropology in Indonesia, Koenjtaraningrat, defines culture as a whole system of ideas, and actions, and also the works of human creativity in order to build community life [9]. So culture can be considered also as a guide for behavior in society. According to the Dictionary of Indonesian Language, culture can be defined as an idea, an intellectuality, and a habit that is difficult to change. This enables culture to be inherited and is not lost in the cultural life of the community as well as to be used as a guideline. There are also several other experts such as Edward and Taylor who reveal that culture is the ability of a person as a result of the person's membership in the society which is eventually led to a new culture in which there are knowledge, belief, art and other capabilities that distinguish one culture with other culture [10]. It also means that culture is the result of interaction between people in a group that produces an idea in which there are knowledge, belief, art, morals, customs and laws that eventually forms a culture.

According to Ki Hajar Dewantara, culture is the result of human mind that comes from human struggles against two strong influences that are nature and age (nature and society) [11]. In addition culture is also an evidence of human achievement in the face of life's obstacles to achieve happiness and salvation that is orderly and safe. Therefore, a nation will be stronger if their culture can be a guide in their lives because every culture has been created through various obstacles to achieve success. A different opinion expressed by C.A. van Peursen who found that manifestation of culture is the life of every person which is different from animals [12]. So it can be said that a person is different from the animals if a person has guidelines on the values contained in the culture. Based on the above definition it can be concluded that the role of culture is very important in the life of a nation because culture is the result of human thought which has the value contained therein. And the value produces characteristic that can be the identity of a nation. Although the use of culture in daily life is abstract but without culture then someone will find it difficult to interact with people

\subsection{The development of Traditional Culture}

In the modern era the pace of development of traditional culture falters due to the growing pace of technology. Besides that the lack of the government's role in handling traditional culture also affects the preservation of the culture. One example is Gambang Semarang. Gambang Semarang, the traditional cultural heritage of Semarang, starts to lose its popularity among the people. The data gathered by the Department of Culture and Tourism Semarang indicate that there are only 7 groups in Semarang since 
2005-2008 that tries to preserve Gambang Semarang. Out of seven groups, there is only one group named Merby under JAYADI owned by Mr. and Mrs. Grace which is still showing Gambang Semarang [5]. This happens because the lack of human resource development and the role of local governments in responding to the preservation of culture. If a culture is preserved then the culture will not be lost . At the same time it will increase local revenue because it attracts foreign tourists to come to the area. In modern age, the regional culture in the form of art begins to be abandoned due to lack of vision and the difficulty of maintaining the authenticity of the arts. In addition, telecommunication development is increasingly easy for people to have a variety of options to enjoy the arts.

\section{RESEARCH METHODOLOGY}

A study required methods to obtain valid data. Therefore, in this study the first thing to do is literature review. Literature review is conducted to strengthen the data that has been obtained and that can be applied.

A literature review was conducted using interviews and observation. The interview was done to the informant from the Public Relations Department of Tourism and Culture of Central Java and Central Java Field Section of Antiquities and Museum Department of Culture and Tourism of the Central Java Province, Mrs Lela. In interview process, there were several questions that are used to obtain information.

Meanwhile, the method of observation was carried out to collect data and information on cultural tourism in Central Java. Information is also obtained from Culture and Tourism Office document entitled "Data of Unmoving Heritage". There are 18 cities and counties that have cultural tourism and most

of the cultural attractions in that book are not widely known to the public.

\section{RESULT AND DISCUSSION}

Interviews conducted by the Public Relations Department of Tourism and Culture in Central Java which obtained 1681 data recorded cultural heritages that exist in Central Java. 113 of such cultural heritage are museums and temples. But not all museums are cultural tourism. So they need screening. After negotiating with the Section Field of Antiquities and Museum Department of Culture and Tourism of the Province of Central Java, Mrs Lela, the data of 15 museums are included in the grouping of cultural tourism.

From the discussions with the Section Field of History, the data suggest a fall and a gap of visitors each year. This happens because the cultural tourism promotion in that particular museum and some temples are not well known to the public. The government has also done a variety of ways such as remodel and rearranges the contents of the museum so that tourists do not easily get bored when visiting the museum. There are also festivals held in the courtyard of the temple or museum so that tourists can enjoy the show while at the same time can learn about the culture. But the promotion is still considered inadequate so their need good media campaign that can attract tourists such as the use of technology.

\section{RESULTS}

There are 1681 cultural heritages in Central Java . 73 tourist cultural destinations is not frequented because they are not known to the society. Hence the need for packaging in the media promotion of cultural tourism is urgent so not only famous museums and temples that get a lot of visitors but also other objects yet known by the public can get visitors. Then, the balance in the preservation of culture in Central Java can be maintained. In addition, the use of technology such as social media and website is also needed to be considered as a medium of promotion. The increasingly developed advanced technology can make rapid spread of information and can spread the area of coverage area. Therefore, the data of not known cultural attractions 
coupled with the use of technology such as social media and website will create a special attraction for tourists because in addition to providing new destinations, it can also be used as the preservation of cultural tourism.

\section{ACKNOWLEDGMENT}

Veinta Sonrizky Mayo gratefully acknowledge

\section{REFERENCES}

[1] F. Nazirun, S. Universitas, and U. Indonesia, "Pembangunan Pariwisata Sebagai Solusi Peningkatan Pendapatan Asli Daerah ( PAD ) Kota Sabang," researchgate, no. August 2013, pp. 1-35, 2016.

[2] Sinoeng N, "Pengembangan Pariwisata Belum Optimal," jatengprov.go.id, 2015. [Online]. Available: http://jatengprov.go.id/id/beritautama/pengembangan-pariwisatabelumoptimal\%C2\%A0\%C2\%A0\%C2\%A0 \%С2\%A0\%C2\%A0\%C2\%A0-.

[3] P. Heru, “Jawa Tengah Canangkan Tahun Infrastruktur Pariwisata," Antara News, JAKARTA, p. 1, 2016.

[4] A. Bahrori and S. Priyatno, "Perancangan Advergame Sebagai Media Promosi Gudeg Yu Djum Berbasis Flash,” Yogyakarta, 2015.

[5] M. M. Jamil, K. Anwar, and A. Kholiq, "Lunturnya Kesenian Tradisional Semarang ( Studi Eksplorasi Kesenian Tradisional Semarang )," Riptek, vol. 5, no. II, pp. 41-51, 2011.

[6] A. Hartanto, R. Timothy, and J. T. Informatika, "Rancang Bangun Edugame Night At School Pada Android Sebagai Media Pembelajaran Siswa Sekolah Dasar," eprints.mdp.ac.id, vol. 7, no. may, pp. 1-9, 2013.
[7] Y. Novalita, A. Rahmawati, P. Studi, I. Keperawatan, F. Keperawatan, and U. Airlangga, "MONAS ( Monopoli Asli Indonesia ) sebagai media bermain untuk membentuk karakter Anak Cinta Indonesia,” PKM KC, vol. 11, no. November, pp. 2-5, 2012.

to Beasiswa Unggulan scholarship support from Bereau for

[8] W. E. P. Lestari, E. N. Sari, A. N. Ramadan, T. E. Wahyuningsih, and Nur Athifah, "Pembuatan Media Pembelajaran Biologi untuk SMP dengan Permainan Monopoli,” PKM KC UNJ, vol. 10, no. November, p. 6, 2013.

[9] Anis Nuryati Suprapto, "Permainan Monopoli Sebagai Media Untuk Meningkatkan Minat Belajar Tata Boga Di Sma,” J. Ilm. Guru “COPE," vol. 6, no. 01, pp. 37 - 43, 2013.

[10] Z. A. SUKMA, "Promosi Kota Solo Melalui Permainan,” Solo, 2010.

[11] Iman, A. D. Indrianto, M. Dzulfikri, A. A. Ghofur, and K. Pratama, “'Polypera'(Monopoly Petualangan Remaja): Permainan Edumoral Antikenakalan Remaja Yang Aplikatif Dan Menyenangkan Di Smp Yapis, Bogor,” PKM-M, vol. 1, no. Februari, pp. 1 - 51, 2014.

[12] Z. Firdaus, S. Zubaidah, and Sunarmi, "Pengembangan Media Pembelajaran Monopoli Ipa Materi Sistem Pencernaan Makanan Untuk Siswa Kelas Viii Di Smp Negeri 4 Malang,” jurnal-online.um.ac.id, vol. 1, no. November, pp. 1-12, 2016.

[13] M. R. Fadha and Y. U. L. Hendra, "Pengenalan Sekolah MTsN Kutablang Menggunakan Augmented Reality Berbasis Android,” pp. 119124. 
[14] A. Okita, Learning C\# programming with Unity 3D. CRC Press, 2014.

[15] F. S. Wijaya, A. Nugroho, and Tinaliah, "Penerapan Algoritma Greedy pada Game Monopoli Indonesia Berbasis Unity 3D," eprints.mdp.ac.id, vol. x, no. November, pp. 1-11, 1978.

[16] M. L. Reyes, J. M. F. Arias, J. J. G. de la Rosa, J. Langer, F. J. B. Outeiriño, and A. Moreno-Muñoz, IT Revolutions: Third International ICST Conference, Córdoba, Spain, March 23-25, 2011, Revised Selected Papers, vol. 82. Springer, 2012.
[17] Sugiyanto and D. Hening, “Game Edukasi ' Ragam Budaya ’ sebagai Media Pembelajaran Budaya tentang Pakaian dan Rumah Adat di Indonesia,” Semin. Nas. Teknol. Inf. Komun. Terap. 2011, vol. 3, no. November, pp. 1 - 7, 2011. 